\title{
Progressive Multifocal Leukoencephalopathy in a Patient with Hepatosplenic T Cell Lymphoma
}

\author{
J. González de la Aleja ${ }^{a} \quad$ E. Giménez-Mesa ${ }^{b} \quad$ I.J. Posada ${ }^{a} \quad$ J.F. Gonzalo-Martínez ${ }^{a} \quad$ R. Bustelo ${ }^{b}$ \\ L. Escudero ${ }^{c}$ \\ Servicios de a Neurología, ${ }^{b}$ Hematología, and ${ }^{\mathrm{c}}$ Radiología, Hospital Universitario 12 de Octubre, Madrid, Spain
}

\section{Dear Sir,}

Progressive multifocal leukoencephalopathy (PML) is a fatal demyelinating disease of the central nervous system caused by the JC polyomavirus. The diagnosis is made on the basis of clinical and neuroradiological criteria with a positive JCV DNA polymerase chain reaction (PCR) in the cerebrospinal fluid or by means of histopathological characteristics [1].

We report the first case, to our knowledge, of PML associated with hepatosplenic T cell lymphoma.

In April 2003, A 56-year-old HIV-negative male was diagnosed with hepatosplenic $\gamma \delta \mathrm{T}$ cell lymphoma. The patient underwent standard chemotherapy with cyclophosphamide, doxorubicine, vincristine and prednisone (CHOP). He failed multiple conventional therapies aimed at controlling his disease, including pentostatine, etoposide, methylprednisolone, cytarabine and cisplatin (ESHAP) and methotrexate, doxorubicin, cyclophosphamide, vincristine, prednisone, and bleomycin (MACOP-B).

In August 2004, the patient was admitted to the hospital because of a rapidly progressive speech disorder. He was afebrile. Neurological examination showed a normal mental status and occasional word-finding difficulties with semantic and paraphasic errors. Cranial magnetic resonance imaging revealed nonenhancing lesion in the left insula and temporal lobe subcortical white matter, without mass effect on $\mathrm{T}_{1}$-weighted images. The lesion was hyperintense on $\mathrm{T}_{2}$ - weighted and on fluid-attenuated inversion recovery magnetic resonance images (fig. 1). Cerebrospinal fluid protein, glucose and cell values were all within the normal ranges. PCR analysis of the cerebrospinal fluid was positive for JC virus DNA. The diagnosis of PML was established. Because of the advanced state of the hematological malignancy, no empirical treatment was applied. The patient died 6 weeks after the onset of his neurological symptoms. The family denied permission for autopsy.

PML was described in 1958 as a rare, fatal complication occurring in the setting of chronic lymphocytic leukemia [2]. With the AIDS epidemic, PML has become one of the deadliest opportunistic infections, strongly correlated with depressed CD4+ lymphocyte counts [1]. However, it is also a rare complication in patients with other immunosuppressive disorders, such as chronic lymphocytic leukemia [3], follicular nonHodgkin's lymphoma, in recipients of renal, heart and lung allografts [4, 5], and allogenic bone marrow transplants due to the pharmacological immunosuppression state [6].

$\mathrm{T}$ cell lymphoma is a lymphoproliferative disorder that causes a profound immunosuppression [7]. Among peripheral T cell lymphomas, hepatosplenic $\gamma \delta \mathrm{T}$ cell lymphoma is a rare and distinct clinicopathologic entity. It usually manifests by splenomegaly and hepatomegaly without lymphadenopathy [8].

The treatment of lymphoproliferative disorders is being increasingly intensified by the introduction of purine nucleoside analogues (fludarabine, pentostatine), thus producing an additional immunosuppres-

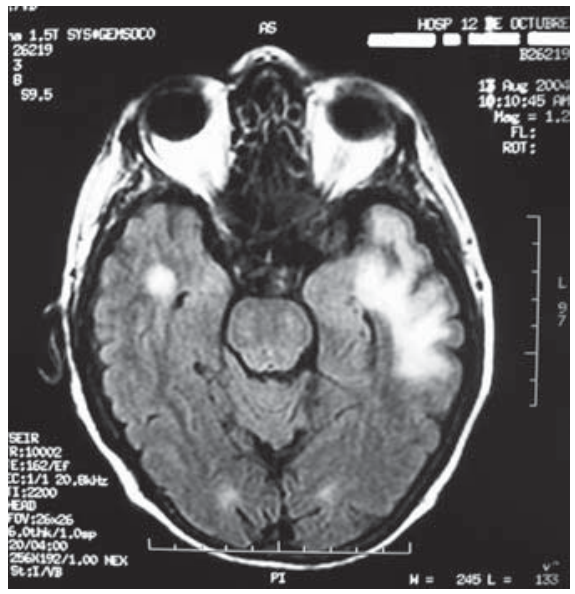

Fig. 1. Hyperintense lesions are seen in both temporal lobes in a fluid-attenuated inversion recovery image. The temporal left lesion is not associated with a mass effect and spares the cortex.

sive effect on T lymphocytes, especially on CD4 lymphocytes $[9,10]$.

To the best of our knowledge, this is the first published case of PML, confirmed by JCV PCR, complicating hepatosplenic T cell lymphoma. The reported patient was treated with different chemotherapeutic agents including pentostatine.

When using agents with effects on Tcell-mediated immunity, we must be aware of the risk of viral opportunistic infections without effective treatment or prophylaxis.

\section{KARGER}

Fax +4161306 1234 E-Mail karger@karger.ch www.karger.com
(C) 2006 S. Karger AG, Base 0014-3022/06/0551-0044\$23.50/0

Accessible online at: www.karger.com/ene
Dr. Jesús González de la Aleja Tejera

Avd. Orovilla $573^{\circ} \mathrm{D}$

ES-28041 Madrid (Spain)

Tel. +3491228 8990, Fax +34913908600

E-Mail Jesus_goal@yahoo.es 


\section{References}

1 Koralnik IJ: New insights into progressive multifocal leukoencephalopathy. Curr Opin Neurol 2004;17:365-370.

2 Astrom K, Mancall EL, Richardson EP: Progressive multifocal leukoencephalopathy: a hitherto unrecognized complication of chronic lymphatic leukemia and Hodgkin's disease. Brain 1958:81:93-111.

3 Bagnato F, Pietropoaolo V, Di Taranto C, Lorenzano S, Toni D: Chronic lymphocytic leukemia complicated by progressive multifocal leukoencephalopathy without apparent immunodepression. Eur J Neurol 2001;8:367368.

4 Lewis AR, Kline LB, Pinkard NB: Visual loss due to progressive multifocal leukoencephalopathy in a heart transplant patient. J Clin Neuroophthalmol 1993;13:237-241.
5 Shitrit D, Nirit L, Shiran SI, Izbicki G, Sofer D, Eldad M, Kramer MR: Progressive multifocal leukoencephalopathy in a lung transplant recipient. J Heart Lung Transplant 2003;22: 946-950.

6 Osorio S, de la Camara R, Golbano N, Marti E, Fedele CG, Nieto S, Manzanares R, Fernandez-Ranada JM: Progressive multifocal leukoencephalopathy after stem cell transplantation, unsuccessfully treated with cidofovir. Bone Marrow Transplant 2002;30:963-966.

7 Yawalkar N, Ferenczi K, Jones DA, Yamanaka K, Suh KY, Sadat S, Kupper TS: Profound loss of T-cell receptor repertoire complexity in cutaneous T-cell lymphoma. Blood 2003;102: 4059-4066.
8 Belhadj K, Reyes F, Farcet JP, Tilly H, Bastard C, Angonin R, et al: Hepatosplenic T-cell lymphoma is a rare clinicopathologic entity with poor outcome: report on a series of 21 patients. Blood 2003;102:4261-4269.

9 Kiewe P, Seyfert S, Korper S, Rieger K, Thiel E, Knauf W: Progressive multifocal leukoencephalopathy with detection of $\mathrm{JC}$ virus in a patient with chronic lymphocytic leukemia parallel to onset of fludarabine therapy. Leuk Lymphoma 2003;44:1815-1818.

10 Saumoy M, Castells G, Escoda L, Mares R, Richart C, Ugarriza A: Progressive multifocal leukoencephalopathy in chronic lymphocytic leukemia after treatment with fludarabine. Leuk Lymphoma 2002;43:433-436. 